\title{
The Acceptance and Use of E-Learning System Among Accounting Lecturers in State and Private Universities in Padang: An Empirical Study Based on UTAUT Model
}

\author{
Henri Agustin ${ }^{1}$, Erly Mulyani² \\ ${ }^{1}$ Department of Accounting, Faculty of Economics, Universitas Negeri Padang, Padang, Indonesia, \\ $\square$ (e-mail) henri_feunp@yahoo.co.id \\ ${ }^{2}$ Department of Accounting, Faculty of Economics, Universitas Negeri Padang, Padang, Indonesia, \\ $\triangle$ (email)erly1978@gmail.com
}

\begin{abstract}
One of the investments of state and private universities to improve the quality of teaching and learning between students and lecturers is the procurement of e-learning system. Due to the large funds of e-learning system investment, the state and private universities need to periodically evaluate whether the lecturers and students have optimally utilized the system. This study aims to find empirical evidence that Unified Acceptance and Use of Technology (UTAUT) model is a conceptual framework to explain the acceptance and use of e-learning system in accounting lecturers of state and private universities in Padang. The sample of this study was 66 lecturers of state and private university in Padang that already implemented e-learning system. The data were obtained by distributing questionnaires directly to accounting lecturers on their respective universities. The data were processed using partial least square (PLS). This study finds the empirical evidence that UTAUT model is able to empirically prove the positive role of performance expectancy, effort expectancy, social influence, and facilitating conditions in improving the intention of accounting lecturers of state and private universities in Padang to use elearning system. However, the model fails to prove the positive role of the intention to use on the actual use of e-learning system.
\end{abstract}

Keywords: e-learning system, UTAUT, lecturers, state universities, Padang

\section{Introduction}

The rapid development of information and communication technology currently causes teaching and learning process can be done online. The phenomenon is often referred to as e-learning, is currently widely adopted by educational institution. For higher education such as universities, except blackboard, WebCT, Desire2Learn, and E-College, Modular Object-Oriented Dinamic Learning Management (MOODLE) is one of the most popular e-learning software platforms used to build elearning systems. In addition to Universitas Negeri Padang (http://e-learning.unp.ac.id), a number of state and private universities in Indonesia who participated using MOODLE as an e-learning system software platform are Gadjah Mada University (http://elisa.ugm.ac.id), Unisula Semarang (http://unisula.ac.id/sinau), AMIKOM Yogyakarta (http://e-learning.amikom.ac.id), Institut Teknologi Bandung (http://kuliah.itb.ac.id), Universitas Parahyangan Bandung (http://e-learning.unpar.ac.id), Universitas Gunadarma Jakarta (http://e-learning.gunadarma.ac.id), Institut Teknologi Surabaya (http:share.its.ac.id), and Brawijaya University (http://inherent.brawijaya.ac.id/vlm) (Sutanta, n.d.).

Teaching and learning process conducted online has a number of advantages over conventional teaching and learning process in general. The first advantage of e-learning lies in the aspect of flexibility. In this case, even if lecturer does not meet directly in the classroom, the teaching and learning process can still take place anywhere and anytime ( 24 hours), by utilizing a number of features available on e-learning systems such as discussion forums, teleconference, quiz, and assignment. The second advantage of e-learning lies in the aspect of material completeness. The existence of e-learning system causes lecturers are motivated to always update the lecture material to improve the quality of teaching 
and learning process. E-learning system enables lecturers to deliver lecture not only in text format (such as power point), but also in audio visual format (such as video and song). Thus, face to face time in the class will be more optimal optimal because more directed to confirmation of understanding (Agustina, 2013; Muzid \& Munir, 2005; Gavira \& Omoteso, 2013).

Apart from a number of positive aspects above, cannot be denied that the optimization of e-learning system at a higher education institution such as universities is determined by the synergy between lecturers, students, managers of e-learning system, and campus leaders. E-learning system will run optimally if both lecturers and students utilize e-learning system in teaching and learning process. While at the same time, the campus leaders and administrators of campus e-learning system provide support in the form of adequate operational budget and competent IT staff. Often, e-learning systems have been established but campus leaders forget to allocate operational budgets and provide competent IT staff. Or e-learning system has been built, IT staff has been provided, but the use of e-learning system is relatively low or not optimal, because there is no obligation for lecturers and students to use it. All of these causes the budget that has been invested by the university to build e-learning system to be in vain. Therefore, research that aims to find out whether e-learning system that has been provided by the campus has been accepted and utilized optimally by lecturers and students become very important.

Unified Theory of Acceptance and Use of Technology (UTAUT) introduced by Venkatesh et.al (2003) is the latest theory that examines the acceptance and use of technology. Venkatesh et al. (2003) reveals that UTAUT's submission is based on a desire to correct weaknesses that lie in the type of technology studied, participants, measurements, and debates between voluntary and mandatory usage in various models/theories of previous technology acceptance. The UTAUT submission is also inseparable from the idea of integrating various models of technology acceptance into a more parsimony model, given the similarity of definitions/concepts found between the constructs of one model and another. For example, performance expectancy constructs are proposed as a frame of similarity between perceived usefulness (TAM) constructs with extrinsic motivation (motivational model), perceived usefulness (TAM) with job-fit (MPCU), and perceived usefulness (TAM) with outcome expectations (SCT), or the construct of social influence is proposed as a frame of similarity between subjective norms (TRA and TPB, TAM 2) and social factors (MPCU) (Hartono, 2008). In their model, Venkatesh et al. (2003) propose performance expectancy, effort expectancy, and social influence as the primary determinants of behavioral intention. Behavioral intention and the facilitating conditions further act as an antecedent of the actual use (actual behavior) of the information system.

Since the UTAUT model was first introduced until now, it is often used as a reference or baseline in various studies of acceptance and use of technology by organizations and individuals. In case of acceptance and acceptance of e-learning system, validity of the UTAUT model can be seen in research by Haghshenas et al. (2012) on the adoption of online education in Malaysia, Wang et al. (2010) on the distance learning acceptance in Taiwan, Wong and Huang (2011) on e-learning system in Taiwan, AlAish and Love (2013) on mobile learning in United Kingdom, Bing Tan (2013) on English languagelearning website in Taiwan, and Khechine et al. (2014) regarding the use of webinar in Canada. As for Indonesia itself, the use of UTAUT model to explain the acceptance of e-learning system can be seen in Sedana and Wijaya (2010) at Sanata Dharma University of Yogyakarta and Prasetyo and Anubhakti (2011) at Budi Luhur University of Jakarta, and Agustin and Mulyani (2016) at Universitas Negeri Padang.

Those previous studies above have one similarity, which is using students as the sample. While research with similar topic using lecturers as a research sample is relatively limited. Students will use e-learning system if their lecturers have or always use e-learning system. And if the lecturer has used e-learning system too, does not guarantee that the lecturer has the same perceptions with the students. There is always the possibility that e-learning utilization by lecturers is limited to what is feared by Love and Fry (2006), which is limited to "online textbook" rather than "supplementary tools" to increase 
the quality of learning process. For this reason, the author argued that research for examine of acceptance and use of e-learning by lecturers is important to do.

This study aims to find empirical evidence that UTAUT is a valid model in explaining the acceptance and use of e-learning system at public and private universities in Padang, the capital of West Sumatera, Indonesia. This research is a continuation of previous research by Agustin and Mulyani (2016) that found empirical evidence on the validity of UTAUT model in explaining acceptance and use of elearning system in accounting students Faculty of Economics, Universitas Negeri Padang. For the manager and leader of public and private universities in Padang, the findings of this research can be used for decision making in optimization and improvement the use and quality of e-learning system in the future. In this case the research hypothesis proposed by the author are as follows:

$\mathrm{H}_{1}$ : Performance expectancy is positively related to behavioral intention to use of e-learning system $\mathrm{H}_{2}$ : Effort expectancy is positively related to behavioral intention to use of e-learning system

$\mathrm{H}_{3}$ : Subjective influences are positively related to behavioral intention to use of e-learning system $\mathrm{H}_{4}$ : Facilitating conditions are positively related to actual use of e-learning system Hs: Behavioral intention to use is positively related to actual use of e-learning system

\section{Methods}

Population of this study is accounting lecturers of undergraduate and graduate program from state and private universities in Padang that already have an e-learning system (Universitas Negeri Padang, Universitas Andalas, STIE-KBP, Politeknik Negeri Padang, and Universitas Dharma Andalas). Number of total population is 112 lecturers, and all of the lecturers was designated as the research sample. The independent variables of the study consist of performance expectancy, effort expectancy, social influence, and facilitating conditions, while the dependent variables are intention to use elearning system and actual use of e-learning system. All of those variables are measured using likert scale from 1 (strongly disagree) to 5 (strongly agree).

This study used a questionnaire contains 27 statements as the instrument of data collection. The questionnaire was adopted from Venkatesh et al (2003) and distributed directly to research sample. All collected data were analyzed with Partial Least Square (PLS). Convergent validity, discriminant, and reliability test are used to measure measurement model (outer model). The rule of thumb used to test the outer model is that the score of each variable indicator is $>0,7$ and the average variance extracted (AVE) and communality is $>0,5$. Structural model (inner model) is used to measure the rate of variance in the dependent variables which can be explained by the independent variables, and also level of significance of path relationship among variables in the model while testing the proposed hypotheses. In this case, the research hypothesis is supported if $t$-statistics $>t$-value (which is 1,96 for two-tailed hypotheses or 1,64 for one-tailed hypotheses (Hartono \& Abdillah, 2009).

\section{Results and Discussion}

Details of data collected based on the number of questionnaire that have been filled and returned to the researchers can be seen in table 1 below.

Table 1 Distribution and Return of Research Questionnaire

\begin{tabular}{lcc}
\hline \multicolumn{1}{c}{ Universities } & Distributed & Returned \\
\hline Universitas Negeri Padang & 18 & 13 \\
\hline Universitas Andalas & 41 & 13 \\
\hline STIE-KBP & 10 & 10 \\
\hline Politeknik Negeri Padang & 26 & 13 \\
\hline Universitas Dharma Andalas & 17 & 17 \\
\hline \multicolumn{1}{c}{ Total } & $\mathbf{1 1 2}$ & $\mathbf{6 6}$ \\
\hline
\end{tabular}


Although this study failed to obtain data from the entire population, the total number of 66 incoming data complies with Chin (2005), which revealed that the minimal amount data required in survey study ranged from 10-15 times the number of research variables. In this case, the minimum number of samples required is 60 people (10 6 people).

The result of measurement model (outer model) test, in order to measure convergent validity, discriminant validity, and reliability can be seen in figure 1, table 2, and table 3 below.

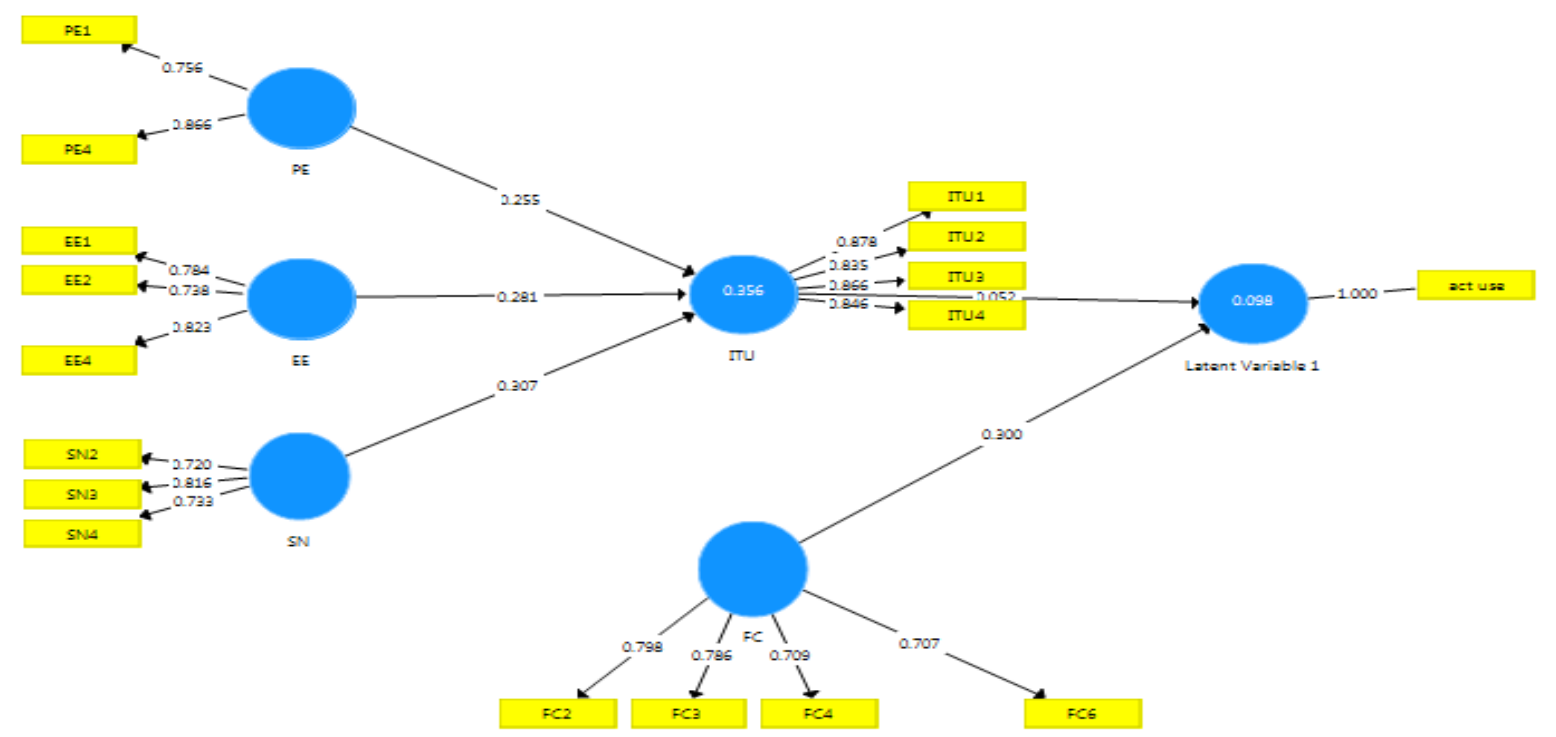

Figure 1 Test Result of Measurement Model (Outer Model)

The data contain in Figure 1, Table 2, and Table 3 above shows that the model proposed has fulfilled all the rule of thumbs required in testing convergent validity, discriminant validity, and reliability test. All the variables used in this study have had a loading factor of $>0,7$. The lowest scores of loading factor for performance expectancy, effort expectancy, social influence, facilitating condition, intention to use, and actual use are 0.756 (PE1); 0.784 (EE1); 0.720 (SN2); 0.707 (FC6); 0.835 (ITU2), respectively.

Table 2 Cross loading Score

\begin{tabular}{lllllll}
\hline & EE & FC & ITU & AU & PE & SN \\
\hline EE1 & $\mathbf{0 . 7 8 4}$ & 0.194 & 0.283 & 0.120 & 0.066 & 0.211 \\
\hline EE2 & $\mathbf{0 . 7 3 8}$ & 0.149 & 0.313 & 0.163 & 0.091 & 0.287 \\
\hline EE4 & $\mathbf{0 . 8 2 3}$ & 0.310 & 0.367 & 0.343 & 0.231 & 0.186 \\
\hline FC2 & 0.225 & $\mathbf{0 . 7 9 8}$ & 0.310 & 0.278 & 0.100 & 0.407 \\
\hline FC3 & 0.217 & $\mathbf{0 . 7 8 6}$ & 0.098 & 0.282 & 0.098 & 0.314 \\
\hline FC4 & 0.106 & $\mathbf{0 . 7 0 9}$ & 0.044 & 0.171 & 0.029 & 0.248 \\
\hline FC6 & 0.355 & $\mathbf{0 . 7 0 7}$ & 0.081 & 0.127 & 0.202 & 0.260 \\
\hline ITU1 & 0.222 & 0.211 & $\mathbf{0 . 8 7 8}$ & 0.043 & 0.447 & 0.400 \\
\hline ITU2 & 0.323 & 0.087 & $\mathbf{0 . 8 3 5}$ & 0.118 & 0.347 & 0.374 \\
\hline ITU3 & 0.455 & 0.232 & $\mathbf{0 . 8 6 6}$ & 0.125 & 0.239 & 0.326 \\
\hline ITU4 & 0.412 & 0.090 & $\mathbf{0 . 8 4 6}$ & 0.076 & 0.300 & 0.459 \\
\hline PE1 & 0.143 & 0.165 & 0.270 & 0.262 & $\mathbf{0 . 7 5 6}$ & 0.365 \\
\hline PE4 & 0.143 & 0.064 & 0.354 & 0.093 & $\mathbf{0 . 8 6 6}$ & 0.117 \\
\hline SN2 & 0.185 & 0.220 & 0.364 & 0.036 & 0.204 & $\mathbf{0 . 7 2 0}$ \\
\hline SN3 & 0.239 & 0.418 & 0.365 & 0.097 & 0.263 & $\mathbf{0 . 8 1 6}$ \\
\hline SN4 & 0.234 & 0.324 & 0.306 & 0.107 & 0.147 & $\mathbf{0 . 7 3 3}$ \\
\hline AU & 0.280 & 0.329 & 0.105 & $\mathbf{1 . 0 0}$ & 0.074 & 0.104 \\
\hline & & & & & &
\end{tabular}


All variables used in this study have a cross loading scores of $>0,7$ for each indicator to the variable. In this case, the lowest cross-loading scores for performance expectancy, effort expectancy, social influence, facilitating condition, intention to use, and actual use are 0.756 (PE1); 0.720 (SN2); 1.0 (AU), 0.738 (EE2); 0.707 (FC6); 0.835 (ITU2), respectively. Finally, all variables used in this study had Cronbach's alpha and composite reliability score of $>0,7$. In this case, the lowest score of Cronbach's alpha and composite reliability are 0.700 (EE, PE, and SN) and 0.795 (PE).

Table 3 Cronbach Alpha and Composite Reliability Score

\begin{tabular}{lll}
\hline Variable & $\begin{array}{l}\text { Cronbach's } \\
\text { Alpha }\end{array}$ & $\begin{array}{l}\text { Composite } \\
\text { Reliability }\end{array}$ \\
\hline EE & 0.700 & 0.825 \\
\hline FC & 0.754 & 0.838 \\
\hline ITU & 0.879 & 0.917 \\
\hline AU & 1.000 & 1.000 \\
\hline PE & 0.700 & 0.795 \\
\hline SN & 0.700 & 0.801 \\
\hline
\end{tabular}

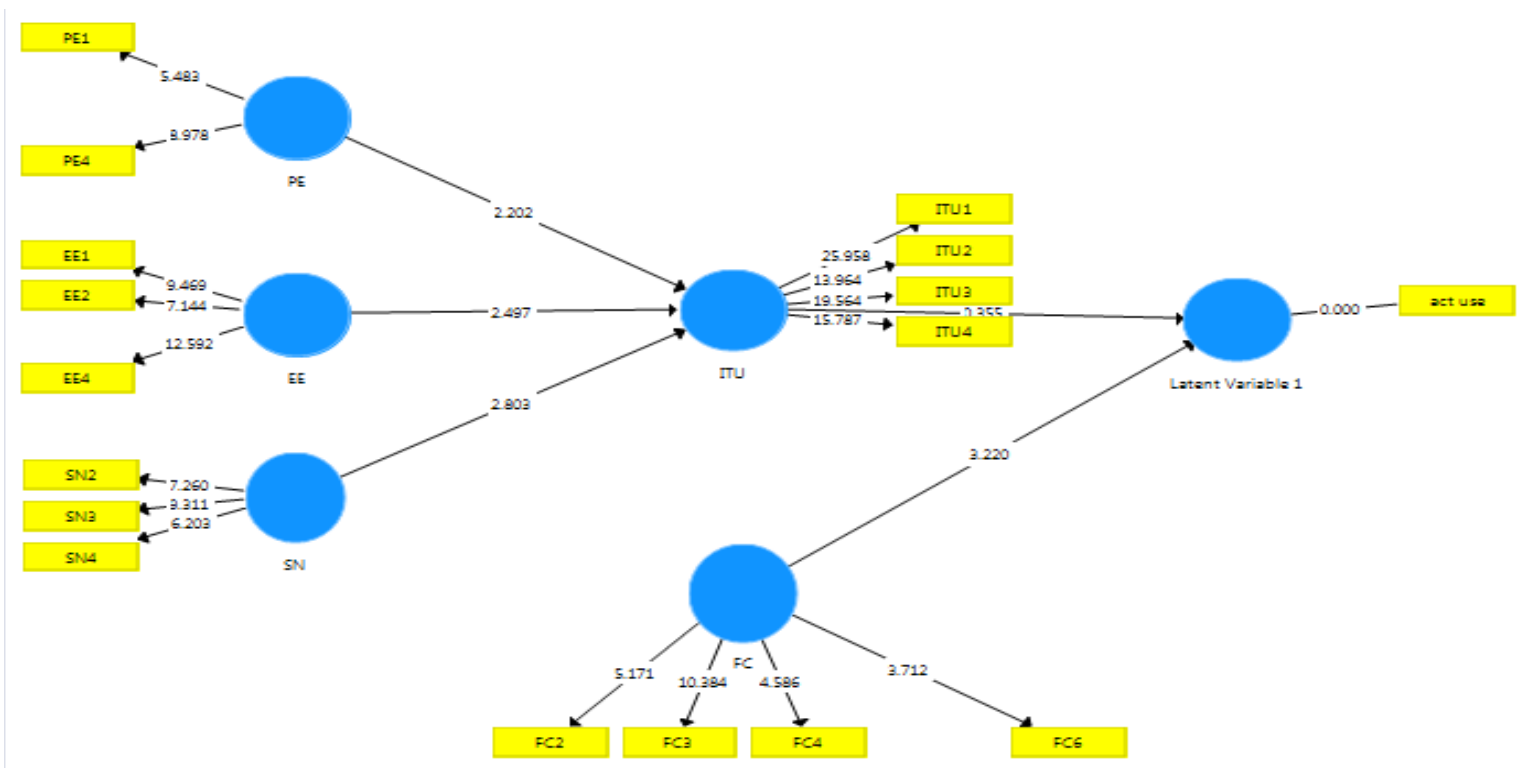

Figure 2 Structural Model Output (Inner Model)

Meanwhile, the output image and summary report of the structural model (inner model) test, which are used to predicting the causal relationship between variables and testing the research hypotheses can be seen in Figure 2, Table 4, and Table 5 below.

Table 4 Path Coefficient of Variables

\begin{tabular}{lllllll}
\hline & $\begin{array}{l}\text { Original } \\
\text { Sample }\end{array}$ & $\begin{array}{l}\text { Sampel } \\
\text { Mean }\end{array}$ & $\begin{array}{l}\text { Standard } \\
\text { Deviation }\end{array}$ & $\begin{array}{l}\text { T- } \\
\text { Statistics }\end{array}$ & P-Value & Sig. \\
\hline PE -> ITU & 0.227 & 0.235 & 0.102 & 2.235 & 0.013 & Supported \\
\hline EE -> ITU & 0.270 & 0.257 & 0.121 & 2.226 & 0.014 & Supported \\
\hline SN -> ITU & 0.306 & 0.227 & 0.120 & 1.715 & 0.044 & Supported \\
\hline FC -> AU & 0.273 & 0.291 & 0.160 & 1.703 & 0.045 & Supported \\
\hline ITU -> AU & 0.091 & 0.101 & 0.158 & 0.577 & 0.282 & Not Supported \\
\hline
\end{tabular}

Table 5 Adjusted R-Square

\begin{tabular}{lr}
\hline ITU & 0.401 \\
\hline AU & -0.007 \\
\hline
\end{tabular}


Based on Figure 2, Table 4, and Table 5 above, it can be seen that this study finds support for hypotheses 1 . It means that performance expectancy has a positive influence to the intention to use elearning system. This finding is consistent with previous studies abroad by Al-Aish and Love (2013), Bing Tan (2013), Haghshenas et al. (2012), Wang et al. (2010), and Khechine et al. (2014), and also support previous studies in Indonesia by Sedana and Wijaya (2010), Prasetyo and Anubhakti (2011), and also Agustin and Mulyani (2016). The support on hypothesis 1 of this study implies that when the accounting lecturers of state and private universities in Padang felt that e-learning system was able to fulfill some of the expectations on the class performance of the teaching and learning process, it further reinforced their intention to re-use the e-learning system. In this case the accounting lecturers of state and private universities in Padang admitted that the quality of the teaching and learning process in the classroom improved after they used the e-learning system. The existence of e-learning system is also acknowledged by lecturers at state and private universities in Padang as a tool that facilitates students to quickly achieve learning outcomes of the courses they taken.

This study also finds support for hypotheses 2. It means that effort expectancy has a positive influence to the intention to use e-learning system. This finding is consistent with previous studies abroad by Al-Aish and Love (2013), Bin Tan (2013), Haghshenas et.al (2012), Wang et.al (2010), and also support previous studies in Indonesia by Prasetyo and Anubhakti (2011)and Agustin and Mulyani (2016). The support on hypothesis 2 of this study implies that when the accounting lecturers of state and private universities in Padang felt that the e-learning system in their campuses is easy to learn and the available features are easy to use.

The findings of this study show that hypotheses 3 is also supported. It means that social influence has a positive influence to the intention to use e-learning system. The findings are consistent with previous studies abroad by Al-Aish and Love (2013), Bin Tan (2013), Haghshenas et.al (2012), Wang et al (2010), Khechine et al (2014), and also support previous studies in Indonesia by Sedana and Wijaya (2010), Prasetyo and Anubhakti (2011), and Agustin and Mulyani (2016). The support on hypothesis 3 of this study implies that the intention of accounting lecturers in state and private universities in Padang to use of e-learning portal becomes stronger when a number of parties on campus that are closely related to them, such as faculty and department leaders, students, or their colleagues always remind them using the e-learning system.

This study also finds support for hypotheses 4 . It means that facilitating conditions has a positive influence to actual use e-learning system. The findings are consistent with previous studies abroad by Bin Tan (2013), Haghshenas et al. (2012), and also support previous studies in Indonesia by Prasetyo and Anubhakti (2011). The support on hypothesis 4 of this study implies if state and private universities in Padang provide a number of resources required by accounting lecturers to utilize e-learning system (e.g. operational manual e-learning system, IT staff, and wi fi), it will strengthen accounting lecturers to be more active using e-learning system more often to support teaching and learning process. The lecturers will be at a disadvantage when they do not optimize the e-learning portal that has been provided by the campus to create a more qualified learning process.

In contrast, this study fails to find support for hypotheses 5 . It means that the intention to use does not affect the actual use of e-learning system. The findings are in contrast to previous studies by Sedana and Wijaya (2010), Prasetyo and Anubhakti (2011), Bin Tan (2013), Hand Aghshenas et al. (2012). It means that the intention of accounting lecturers of state and private universities in Padang to use elearning system would not automatically became actual use, when they found a number of things that degrade it. For example, the use of e-learning system is not mandatory so there is no punishment or negative consequences for lecturers who do not use it. Intention to use also will not result in the actual use of e-learning portal for accounting lecturers of state and private universities in Padang, if the elearning portal has not been integrated as an additional or complementary element in the learning activities in the classroom. As a result, lecturers and students will continue to rely on face-to-face meetings as the only source of learning activities. 
All proposed independent variables (performance expectancy, effort expectancy, social influence, and facilitating conditions) only explain $40,1 \%$ of variance that occurs on the intention to use e-learning system. This also implies that the level of the variance in intention to use e-learning system explained by three variables proposed is in a moderate range.

\section{Conclusions}

UTAUT model which is proposed by Venkatesh et al. (2003) only able to partially explain the acceptance and use of e-learning system among accounting lecturers of state and private universities in Padang, the capital of West Sumatera Province Indonesia. The study has empirically proven the positive role of performance expectancy, effort expectancy, social influence, and facilitating conditions with the intention to use e-learning system, but failed to empirically prove the positive role of intention to use with the actual use of e-learning system.

This study has two weaknesses. First, this study has a low adjusted R square. The combination of performance expectancy, effort expectancy, social influence, and facilitating conditions in explaining the change of variance in intention to use e-learning system is only $40,1 \%$. So, further studies in the same topic should include new variables or develop new model. Second, this study is a cross sectional research. Thus, data obtained is reflection of the perception of accounting lecturers of state and private universities in Padang at a certain time. Meanwhile, perception is something that is dynamic and could change in the future. So, it is advisable to the university management to conduct periodic survey to explore the perception of lecturers and students on e-learning system of its university, and published rule that using e-learning system is mandatory for every students and lecturers. Thus, large investments that have been issued to build e-leaning system is not wasted.

\section{References}

Al-Aish, Ahmad and Love, Steve. (2013). Factor influencing student's acceptance of e-learning: An investigation in higher education. The International Review of Research in Open and Distance Learning, 14(5), 82-107. Retrieved from http://irrodl.org/index.php/irrodl/article/view/1631.

Agustina, Merry. (2013, 15 Juni). Pemanfaatan e-learning sebagai media pembelajaran. Paper presented at Seminar Nasional Aplikasi Teknologi Inforrmasi (SNATI). http://journal.uii.ac.id/Snati/article/ view/3064.

Agustin, Henri and Mulyani, Erly. (2016, 6 Agustus). Model Penerimaan E-Learning: Studi Empiris Pada Mahasiswa Akuntansi Fakultas Ekonomi Universitas Negeri Padang. Paper presented at Seminar Nasional Aplikasi Teknologi Inforrmasi (SNATI). http://journal.uii.ac.id/Snati/article/view/6257.

Bing Tan, Paul Juinn. (2013). Applying the UTAUT to Understand Factors Affecting the Use of English ELearning Websites in Taiwan. Retrieved from http://www.sagestateation.com/content/3/4/2158244 013503837.

Gavira, Rosario Lopez and Omoteso, Kamil. (2013). Perceptions of the usefulness of virtual learning environments in accounting education: a comparative evaluation of undergraduate accounting students in spain and england. Accounting Education: An International Journal, 22(5), 445-466. Retrieved from https://doi.org/10.1080/09639284.2013.814476.

Hartono, Jogiyanto. (2008). Sistem informasi keprilakuan. Edisi Revisi. Yogyakarta: Penerbit Andi

Hartono, Jogiyanto and Abdillah, Willy. (2009). Konsep dan aplikasi PLS untuk penelitian empiris. Yogyakarta: Penerbit BPFE.

Haghshenas, H., Chatroudi, E. A., \& Njeje, F. A. (2012). Does educational level matter in adopting online education? A Malaysian perspective. Journal of Marketing for Higher Education, 22(1), 117-151. Retrieved from https://doi.org/10.1080/08841241.2012.705798.

Khechine, Hager; Lakhal, Sawsen; Pascot, Daniel; and Bytha, Alphonse. (2014). UTAUT model for blended learning: the role of gender and age in the intention to use webinars. Interdisciplinary Journal of E-learning and Learning Objects, 10, 33-52. Retrieved from https://pdfs.semanticscholar. org/6f7c/3f4d18b3d1418300232d98ca6e7cb60179db.pdf. 
Love, N and Fry, N. (2006). Accounting student's perceptions of a virtual learning environment: springboard or safety net?. Accounting Education: An International Journal, 15(2), 151-166. Retrieved from https://doi.org/10.1080/06939280600609201.

Muzid, Syaiful and Munir, Mishbahul. (2005). Persepsi mahasiswa dalam penerapan e-learning sebagai aplikasi peningkatan kualitas pendidikan (studi kasus pada universitas islam Indonesia). Paper presented at Seminar Nasional Aplikasi Teknologi Inforrmasi (SNATI). http://journal.uii.ac.id/Snati/article/ view/1301

Prasetyo, Basuki and Anubhakti, Dian. (2011). Kajian penerimaan sistem e-learning dengan menggunakan pendekatan UTAUT: studi kasus fakultas teknologi informasi universitas budi luhur. BIT. 8(2), 45-47. Retrieved from http://riset.budiluhur.ac.id/wp-content/uploads/2012/02/ BIT-08-2-08.pdf.

Sedana, I Gusti Nyoman and Wijaya, Wisnu. (2010). UTAUT model for understanding learning management system. Internetworking Indonesia Journal, 2(2), 27-32. Retrieved from http://www.internetworkingindonesia.org/Issues/Vol2-No2-Fall2010/iij_vol2_no2_2010_sedana. pdf.

Sutanta, Eddy. (2015). Konsep dan Implementasi E-Learning: Studi Kasus Pengembangan E-Learning di SMAN 1 Sentolo Yogyakarta. Retrieved from https://www.researchgate.net/publication/228343752 KONSEP_DAN_IMPLEMENTASI_E-LEARNING_Studi_Kasus_Pengembangan_E-Learning_di_ SMA_N_1_Sentolo_Yogyakarta.

Venkatesh, V; Morris, M.G; Davis, G.B and Davis, F.B. (2003). User acceptance of information technology: toward a unified view. MIS Quarterly, 27(3), 425-478. Retrieved from http://web.a. ebscohost.com/bsi/pdfviewer/pdfviewer?vid=16\&sid=38f99af4-a8d1-47db-b4c83e1e $44887 \mathrm{fd} 8 \% 40$ sessionmgr4010.

Wang, Chih-Hsing; Liu, Wen-Liang; Tseng, Meng-Chun, Tsai, Hung-Sung. (2010). A study of taiwannese college teachers' acceptance of distance learning. International Journal of Organizational Innovation, 3(2), 243-260. Retrieved from http://web.a.ebscohost.com/bsi/pdfviewer/pdfviewer? vid=10\&sid=38f99af4-a8d1-47db-b4c8-3e1e44887fd8\%40sessionmgr4010.

Wong, Wan-Tzu and Huang, Neng Tang Norman. (2011). The effects of e-learning system service quality and user acceptance on organizational learning. International Journal of Business and Information, 6(2), 205-225. Retrieved from https://ijbi.org/ijbi/article/view/62/66 